\title{
An Analysis of the Present Situation and Influencing Factors of Property Insurance
}

\author{
Zhang Xuefeng \\ School of Economics and Management \\ North China University of Technology \\ Beijing, China \\ E-mail: zxf511@163.com
}

\author{
Zhang Qian \\ School of Economics and Management \\ North China University of Technology \\ Beijing, China \\ E-mail: 528690807@qq.com
}

\begin{abstract}
Since the reform and opening up, especially after China's accession to the WTO, insurance has entered a new historical development period in China. As a branch of commercial insurance, property insurance still has great potential for development under the current economic situation. Firstly, this paper analyzes the present situation of property insurance in China, Then, combining with econometrics, statistics and other related theories and using log linear multiple regression model, this paper tries to find out the factors affecting China's property insurance demand, and the results show that the per capita disposable income of urban residents has a greater impact on the property insurance density in different regions.
\end{abstract}

Keyword-Property insurance; Elasticity; Log linear multiple Regression model; Influence factors

\section{INTRODUCTION}

Objectively, property insurance is now meeting the needs of various risk protection (In addition to the body and life of a natural person), It is an indispensable economic compensation system for the development of contemporary society. The purpose of this paper is to find out the factors that influence the development of property insurance industry. Maria Teresa Medeiros Garcia [1] tried to find out the relationship between property-liability insurance premiums and economic and financial development in the case of Portugal, The paper conducts OLS estimations, The results show that the level of the gross domestic product is the only factor explaining the level of property-liability insurance demand in Portugal.J. David Cummins and RichardA. Derrig [2] illustrated the use of FST, The results indicate that FST can lead to significantly different decisions than the conventional approach. Zhen YANG, Junwen FENG [3] analyzed the connotation of sustainable development ability; determines three main factors (capability resources, capability level and capability environment) and their sub-factors, lays out the structural model of the sustainable development capability of property insurance enterprises. In this model, capability environment is the basis and capability resources and capability level are the pillars.

\section{OVERVIEW OF PROPERTY INSURANCE}

\section{A. The concept and characteristics of property insurance}

Property insurance takes all kinds of property, materials and related interests as the object of insurance, It is a kind of socialized economic compensation system that compensates the economic loss of the insured.

The characteristics of Property insurance are as follows(1)Diversity of objects(2)The particularity of insurance object(3)The particularity of insurance interest(4)The particularity of determining the amount of insurance(5)The particularity of insurance period(6)The particularity of insurance contract.

\section{B. Comparison of insurance density of property insurance}

Premium income is a holistic concept, and the insurance density is a concept of per capita. It marks the development of regional insurance business, It also reflects the situation of economic development and the awareness of insurance in the region, Therefore, it shows the popularity of insurance related knowledge. generally speaking, the index of insurance density is greater, The development of insurance industry in the region is better, The popularity of insurance knowledge is higher.

The calculation formula of insurance density is as follows:

Insurance density= Annual insurance income in the region/ The number of resident population in the region

In 2015 , the density of property insurance in each region and the rankings were shown in table 1 .

Supported by the North China University of Technology "The belt and Road" countries talent training base project and Beijing Municipal Commission of Education fundamental research funds (Grant No.110052971803-056) 
TABLE I THE DENSITY OF PROPERTY INSURANCE IN EACH REGION AND THE RANKINGS IN 2015

\begin{tabular}{|c|c|c|c|c|c|}
\hline Name of region & $\begin{array}{l}\text { Density of property } \\
\text { insurance (yuan) }\end{array}$ & ranking & Name of region & $\begin{array}{l}\text { Density of property } \\
\text { insurance (yuan) }\end{array}$ & ranking \\
\hline Beijing & 1566.43 & 1 & Shanxi & 470.48 & 17 \\
\hline Shanghai & 1471.46 & 2 & Jilin & 452.9 & 18 \\
\hline Zhejiang & 1104.64 & 3 & Anhui & 444.95 & 19 \\
\hline Jiangsu & 842.74 & 4 & Qinghai & 443.88 & 20 \\
\hline Tianjin & 777.53 & 5 & Shanxi & 435.01 & 21 \\
\hline Guangdong & 689.01 & 6 & Yunnan & 424.28 & 22 \\
\hline Ningxia & 614.03 & 7 & Hubei & 407.59 & 23 \\
\hline Xinjiang & 605.78 & 8 & Guizhou & 376.22 & 24 \\
\hline Inner Mongolia & 594.5 & 9 & Hunan & 358.56 & 25 \\
\hline Fujian & 577.07 & 10 & Heilongjiang & 348.65 & 26 \\
\hline Liaoning & 563.15 & 11 & Gansu & 347.36 & 27 \\
\hline Hebei & 538.05 & 12 & Tibet & 343.83 & 28 \\
\hline Sichuan & 513.15 & 13 & Henan & 339.3 & 29 \\
\hline Chongqing & 512.04 & 14 & Guangxi & 306.8 & 30 \\
\hline Hainan & 486.13 & 15 & Jiangxi & 305.46 & 31 \\
\hline Shandong & 480.69 & 16 & & & \\
\hline
\end{tabular}

As shown in table 1 , The average density of property insurance in China was 572.3119 yuan in 2015, Insurance density in Beijing, Shanghai and Zhejiang is the top three, Henan, Guangxi and Jiangxi are the latter three, The insurance density is less than 340 yuan, The density of property insurance in Beijing is 1566.43 yuan, It ranks first, Therefore, the development of insurance industry in Beijing is relatively mature, People have strong awareness of insurance, The popularity of property insurance is also high, The density of property insurance is higher than the average in 10 regions, The index is greatly influenced by demographic factors, Such as Xinjiang, If you only focus on the premium income of property insurance, the ranking is back, However, the ranking of insurance density is relatively high, The reason may be that the population of Xinjiang is relatively small.

\section{Comparison of insurance depth of property insurance}

Insurance depth refers to the ratio of premium income to the gross domestic product (GDP) in the region, It reflects the position of the insurance industry in the whole national economy. The insurance depth depends on the overall economic development level of a country and the development speed of insurance industry. Generally speaking, The greater the index of insurance depth, It shows that in the process of regional economic development, The insurance industry has made a great contribution to economic growth.

In 2015, the depth and rank of property insurance in different areas are listed in Table 2 below:

TABLE II IN 2015, THE DEPTH OF REGIONAL PROPERTY INSURANCE AND ITS RANKINGB

\begin{tabular}{|c|c|c|c|c|c|}
\hline Name of region & $\begin{array}{l}\text { Depth of property } \\
\text { insurance }(\%)\end{array}$ & ranking & Name of region & $\begin{array}{l}\text { Depth of property } \\
\text { insurance }(\%)\end{array}$ & ranking \\
\hline Xinjiang & 1.53 & 1 & Liaoning & 1 & 17 \\
\hline Zhejiang & 1.5 & 2 & Shanxi & 1 & 18 \\
\hline Beijing & 1.48 & 3 & Chongqing & 0.98 & 19 \\
\hline Yunnan & 1.45 & 4 & Jiangsu & 0.96 & 20 \\
\hline Shanghai & 1.42 & 5 & Fujian & 0.89 & 21 \\
\hline Ningxia & 1.41 & 6 & Heilongjiang & 0.89 & 22 \\
\hline Sichuan & 1.4 & 7 & Jiangxi & 0.88 & 23 \\
\hline Hebei & 1.34 & 8 & Guangxi & 0.88 & 24 \\
\hline Gansu & 1.33 & 9 & Henan & 0.86 & 25 \\
\hline Guizhou & 1.26 & 10 & Hunan & 0.84 & 26 \\
\hline Shanxi & 1.24 & 11 & Jilin & 0.84 & 27 \\
\hline Guangdong & 1.21 & 12 & Inner Mongolia & 0.83 & 28 \\
\hline Anhui & 1.21 & 13 & Hubei & 0.81 & 29 \\
\hline Hainan & 1.2 & 14 & Shandong & 0.75 & 30 \\
\hline Tibet & 1.09 & 15 & Tianjin & 0.73 & 31 \\
\hline Qinghai & 1.08 & 16 & & & \\
\hline
\end{tabular}


As shown in table 2, The average depth of property insurance in China was $1.1061 \%$ in 2015. The insurance depth of Xinjiang, Zhejiang, Beijing, Yunnan, Shanghai, Ningxia, Sichuan, Hebei, Gansu, Guizhou, Shanxi, Guangdong, Anhui and Hainan is higher than the average level in China, Hubei, Shandong and Tianjin are in the latter three.

The insurance depth in Beijing is $1.48 \%$, ranking third, This shows that in the process of economic growth, The contribution of insurance industry to economic growth in Beijing is relatively large, But the insurance depth in Beijing is only about 0.38 percentage points higher than the average in china, This explains, Even if in areas where the economy is booming, Property insurance still has a lot of room for improvement, There are also many aspects to be perfected.
D. The influence of gross domestic product on the premium income of property insurance companies

Regional gross domestic product (100 million yuan): The final results of production activities in a given period of time by all the resident units in the region.

The change of property insurance demand caused by the change of GDP can be expressed by the elasticity, Such as formula (1).

$$
E_{m}=\frac{\Delta Q / Q}{\Delta I / I}
$$

Among them: $E_{m}$ represents the elasticity of income, $Q$ represents the premium income of the property insurance, $I$ represents total value of GDP

TABLE III ELASTICITY TABLE OF PREMIUM INCOME OF PROPERTY INSURANCE COMPANY

\begin{tabular}{|c|c|c|c|c|c|}
\hline years & $\begin{array}{c}\text { Gross Domestic } \\
\text { Product (100 million } \\
\text { yuan) }\end{array}$ & $\begin{array}{c}\text { GDP growth rate } \\
(\%)\end{array}$ & $\begin{array}{c}\text { Property insurance } \\
\text { company's premium } \\
\text { income (100 million } \\
\text { yuan) } \\
\end{array}$ & $\begin{array}{c}\text { Premium income } \\
\text { growth rate of property } \\
\text { insurance companies } \\
(\%) \\
\end{array}$ & $\begin{array}{c}\text { The elasticity of } \\
\text { premium income of } \\
\text { property insurance } \\
\text { companies to GDP }\end{array}$ \\
\hline 2001 & 110863.1 & & 691 & & \\
\hline 2002 & 121717.4 & 0.097907 & 772 & 0.117221 & 1.19727 \\
\hline 2003 & 137422 & 0.129025 & 866 & 0.121762 & 0.943705 \\
\hline 2004 & 161840.2 & 0.177688 & 1125 & 0.299076 & 1.683156 \\
\hline 2005 & 187318.9 & 0.157431 & 1284 & 0.141333 & 0.897747 \\
\hline 2006 & 219438.5 & 0.17147 & 1581 & 0.231308 & 1.348972 \\
\hline 2007 & 270232.3 & 0.231472 & 2087 & 0.320051 & 1.382677 \\
\hline 2008 & 319515.5 & 0.182373 & 2446 & 0.172017 & 0.943214 \\
\hline 2009 & 349081.4 & 0.092534 & 2993 & 0.22363 & 2.41675 \\
\hline 2010 & 413030.3 & 0.183192 & 4027 & 0.345473 & 1.885851 \\
\hline 2011 & 489300.6 & 0.18466 & 4779 & 0.18674 & 1.01126 \\
\hline 2012 & 540367.4 & 0.104367 & 5530 & 0.157146 & 1.505705 \\
\hline 2013 & 595244.4 & 0.101555 & 6481 & 0.171971 & 1.693379 \\
\hline 2014 & 643974 & 0.081865 & 7544 & 0.164018 & 2.00352 \\
\hline 2015 & 685505.8 & 0.064493 & 8423 & 0.116516 & 1.806653 \\
\hline
\end{tabular}

According to the relevant data, The calculation results are shown in Table 3, The results show that in addition to individual years, The value of elasticity is greater than 1 , On the whole, it's resilient, Property premium income will increase significantly with the growth of GDP.

\section{ANALYSIS OF PROPERTY INSURANCE DEMAND BASED ON ECONOMETRIC MODEL}

\section{A. The determination of independent variable}

Among the economic indicators, I've chosen some indicators that are closely related to property insurance, As follows:

Unemployment rate (\%);Financial revenue (100 million yuan); Green coverage rate of built-up area (\%);Per capita net income of farmers (yuan); Proportion of urban population at the end of the year (\%); Final consumption expenditure (100 million yuan); Per capita disposable income of urban residents (yuan); Regional GDP (100 million yuan)
To determine whether the above factors can have a significant impact on the density of property insurance, Next, I use stepwise regression to choose: 
TABLE IV COEFFICIENT

\begin{tabular}{|c|c|c|c|c|c|c|}
\hline \multirow{2}{*}{\multicolumn{2}{|c|}{ Model }} & \multicolumn{2}{|c|}{ Non standardized coefficient } & \multirow{2}{*}{$\begin{array}{c}\text { Standard coefficient } \\
\text { Trial version }\end{array}$} & \multirow[b]{2}{*}{$\mathbf{t}$} & \multirow[b]{2}{*}{ Sig. } \\
\hline & & $B$ & Standard error & & & \\
\hline \multirow[t]{2}{*}{1} & (constant) & -599.143 & 84.410 & & -7.098 & .000 \\
\hline & $\begin{array}{c}\text { Per capita disposable income of } \\
\text { urban residents (yuan) }\end{array}$ & .040 & .003 & .936 & 14.272 & .000 \\
\hline \multirow[t]{3}{*}{2} & (constant) & -653.029 & 81.880 & & -7.975 & .000 \\
\hline & $\begin{array}{c}\text { Per capita disposable income of } \\
\text { urban residents (yuan) }\end{array}$ & .044 & .003 & 1.041 & 13.725 & .000 \\
\hline & $\begin{array}{l}\text { Financial revenue (100 million } \\
\text { yuan) }\end{array}$ & -.025 & .011 & -.177 & -2.339 & .027 \\
\hline \multirow[t]{4}{*}{3} & (constant) & -726.802 & 83.842 & & -8.669 & .000 \\
\hline & $\begin{array}{c}\text { Per capita disposable income of } \\
\text { urban residents (yuan) }\end{array}$ & .037 & .004 & .884 & 8.762 & .000 \\
\hline & $\begin{array}{l}\text { Financial revenue (100 million } \\
\text { yuan) }\end{array}$ & -.026 & .010 & -.181 & -2.539 & .017 \\
\hline & $\begin{array}{c}\text { Proportion of urban population at } \\
\text { the end of the year }(\%)\end{array}$ & 4.798 & 2.186 & .203 & 2.195 & .037 \\
\hline
\end{tabular}

The selected factors are respectively: $x_{1}$ represents $\ln y=\beta_{1} \ln x_{1}+\beta_{2} \ln x_{2}+\beta_{3} \ln x_{3}+\mu$

financial revenue (100 million yuan), $x_{2}$ represents proportion of urban population at the end of the year $(\%)$,

represents per capita disposable income of urban residents (yuan)

\section{B. The establishment of the model}

The disturbance of multicollinearity has been reduced in the stepwise regression process mentioned above, Log multiple linear regression model was selected, Not only because it can overcome a certain degree of multicollinearity, It also reflects when a variable changes $1 \%$, The change of another variable.

Among them, $y$ represents density of property insurance (yuan), $x_{1}$ represents financial revenue (100 million yuan), $x_{2}$ represents proportion of urban population at the end of the year (\%), $x_{3}$ represents per capita disposable income of urban residents (yuan), $\mu$ represents random disturbance term

Regression of sample data using Eviews:

TABLE V THE RESULT OF REGRESSION

\begin{tabular}{|c|c|c|c|c|}
\hline Variable & Coefficient & Std. Error & t-Statistic & Prob. \\
\hline LOG(X2) & 0.635416 & 0.208643 & 3.045475 & 0.0051 \\
\hline $\mathbf{C}$ & -10.87502 & 1.880447 & -5.783208 & 0.0000 \\
\hline LOG(X3) & 1.493280 & 0.231988 & 6.436882 & 0.0000 \\
\hline LOG(X1) & -0.097969 & 0.044059 & -2.223569 & 0.0347 \\
\hline R-squared & 0.837867 & \multicolumn{2}{|c|}{ Mean dependent var } & 6.253258 \\
\hline Adjusted R-squared & 0.819852 & \multicolumn{2}{|c|}{ S.D. dependent var } & 0.413504 \\
\hline S.E. of regression & 0.175507 & \multicolumn{2}{|c|}{ Akaike info criterion } & -0.522365 \\
\hline Sum squared resid & 0.831670 & \multicolumn{2}{|c|}{ Schwarz criterion } & -0.337335 \\
\hline Log likelihood & 12.09666 & \multicolumn{2}{|c|}{ Hannan-Quinn criter. } & -0.462050 \\
\hline F-statistic & 46.51007 & \multicolumn{2}{|c|}{ Durbin-Watson stat } & 1.314841 \\
\hline $\operatorname{Prob}(F-$-statistic) & 0.000000 & & & \\
\hline
\end{tabular}

From table 4, Adjusted R-squared is greater than 0.8, The overall fitting degree of the equation is better, By F statistics,
The equation is significant on the whole, The $\mathrm{P}$ values of each variable were less than the significant level of 0.05 , Zero 
hypothesis is rejected, It is shown that the independent variables of the equation are significant.

\section{Model testing}

In order to build a high quality model, The heteroscedasticity of the equation is tested:

White's general variance test was used, There are 3 independent variables in the model, The auxiliary regression model is as follows:

$$
\begin{aligned}
& \tilde{e}_{i}^{2}=\alpha_{0}+\alpha_{1} \ln x_{1 i}+\alpha_{2} \ln x_{2 i}+\alpha_{3} \ln x_{3 i}+\alpha_{4}\left(\ln x_{1 i}\right)^{2}+\alpha_{5}\left(\ln x_{2 i}\right)^{2}+ \\
& \alpha_{6}\left(\ln x_{3 i}\right)^{2}+\alpha_{7} \ln x_{1 i} \ln x_{2 i}+\alpha_{8} \ln x_{1 i} \ln x_{3 i}+\alpha_{9} \ln x_{2 i} \ln x_{3 i}+\varepsilon_{i}
\end{aligned}
$$

Among them, $\tilde{e}_{i}^{2}$ represents the square of the residuals of the model, $\varepsilon_{i}$ represents random error term

The output is shown in table 4:

\section{TABLE VI Heteroskedasticity Test: White}

\begin{tabular}{cc} 
F-statistic & 0.504358 \\
Obs*R-squared & 5.509799 \\
\hline
\end{tabular}

The value of $p$ is greater than 0.05 for the significance level, It is preliminarily believed that the model does not exhibit heteroscedasticity.

So the model can be expressed as

$$
\begin{aligned}
\ln y= & -10.87502-0.097969 \ln x_{1} \\
& +0.635416 \ln x_{2}+1.493280 \ln x_{3}
\end{aligned}
$$

\section{CONCLUSION}

The density of property insurance premiums has a negative correlation with Revenue, The elasticity is -0.097969 , The absolute value of elasticity is close to 0 , That is to say, the growth of financial revenue has little effect on the density of property insurance. One reason is that financial revenue includes a variety of income, financial revenue can only explain the level of economic development of the country as a whole, Its increase or decrease have little influence on the development of insurance industry; Another reason is that the density of property insurance is a concept of per capita, Even if property premiums will vary substantially with the growth of financial revenue, But there are so many people in China, After average, the change of the premium density will not be obvious.

The density of property insurance has a positive correlation with the proportion of urban population at the end of the year. The elasticity is 0.635416 , That is to say, the proportion of urban population increased by $1 \%$ at the end of the year, The premium density of property insurance increased by 0.635416 percentage points. The education level of urban population is higher, Their income and living standards are mostly moderate or better, The ability to accept new things is stronger, In areas with a large proportion of urban population, People pay more attention to financial management, Insurance coverage and approval rates will also be higher, Therefore, the consciousness of insurance is stronger.

The density of property insurance is positively related to the per capita disposable income of urban residents. The

\begin{tabular}{cc} 
Prob. F(9,21) & 0.8549 \\
Prob. Chi-Square(9) & 0.7878 \\
\hline
\end{tabular}

elasticity is 1.493280 , That is, the per capita disposable income of urban residents increased by $1 \%$, The density of property insurance increased by 1.493280 percentage points. The per capita disposable income of urban residents reflects that the total cash income of residents can be used to arrange the income of family daily life, This factor has the most significant effect on the premium density of property insurance, The areas with high per capita disposable income of urban residents, In terms of finance, public services, education and health care, their development is relatively mature, Residents in these areas have a deeper sense of insurance, They can take the initiative to buy the insurance they need, So the density of property insurance will be affected.

\section{REFERENCES}

[1] Maria Teresa Medeiros Garcia. Determinants of the property-liability insurance market: evidence from Portugal[J]. Journal of Economic Studies,2012,39(4):440-450.

[2] J. David Cummins,RichardA. Derrig. Fuzzy Financial Pricing of Property-Liability Insurance[J]. North American Actuarial Journal,1997,1(4):21-40.

[3] Zhen YANG,Junwen FENG. Basic Factors Influencing the Sustainable Development Capability of Chinese Property and Casualty Insurance Enterprises[J]. Management Science and Engineering,2013,7(2):109-116.

[4] Shao Fu Song,Guang Jin Li, Ying Sheng Su. The Fuzzy Comprehensive Assessment of Brand Competitiveness of Property Insurance Companies[J]. Applied Mechanics and Materials,2011,1245(55):14891493.

[5] Hui-Yin Tsai,Bao-Huey Huang,AnSiou Wang. Performance evaluation model of property-liability insurance companies in Taiwan - application of analysis network process[J]. Journal of Information and Optimization Sciences, 2008,29(6):1045-1065.

[6] Enoch Nii Boi Quaye,Charles Andoh,Anthony Q.Q. Aboagye. Loss reserve variability and loss reserve errors: An empirical analysis of the Ghanaian property and liability insurance industry[J]. The Journal of Risk Finance,2014,15(3):248-263.

[7] Zhang Xiaotong. Eviews usage guidelines and cases [M]. Beijing : Machinery Industry Press, 2007.

[8] Li Zinai, Pan Wenqing. Econometrics (Third Edition) [M]. Beijing : Higher Education Press, 2010.

[9] Zhang Xiaotong. Applied quantitative economics [M]. Beijing : Machinery Industry Press,2009. 